\section{Biletska Y., Semeniuk A., Perepelytsia A.}

\title{
RESEARCH OF THE INFLUENCE OF SOYBEAN GERMINATION ON CHANGES IN THE AMINO ACID COMPOSITION AND THE CONTENT OF PHYTIC ACID
}

\begin{abstract}
Забезпечення населення екологічно чистими білковими харчовими продуктами рослинного походження є важливим завданням державного значення будь-якої краӥни. Проте нативне використання бобів сої на съогодні обмежене через наявність у них антипоживних речовин, а саме вмістом фітинової кислоти, яка здатна підвищувати утворення кишкового газу. Знизити вміст фітинової кислоти в бобових можливо під час процесу пророщення. Рослинний білок, який є основною складовою бобових культур, має здатність до акумуляції неорганічних мікроелементів, трансформуючи їх в органічні форми під час замочування у процесі пророщення. Об’єктом дослідження обрано ранньостиглий сорт сої «Алмаз» з вмістом білка 43,88 \% врожаю 2018 року з колекційного розсадника «Агротек» (м. Київ, Україна). Характеристика розчинів для замочування була із концентрацією йодиду калію 38 г/1000 $\mathrm{cm}^{3} \mathrm{H}_{2} \mathrm{O}$, що відповідає вмісту йоду в розчинах 41 мкг/г і задовольняе 1/3 \% добової потреби в йоді. Зерно замочували на 48 годин. В ході дослідження використовували метод іонообмінної хроматографії, амінокислотний аналізатор ААA Т-339М (Чехія) та хроматограф TM Shimadzu LC-20 (Японія). Вміст фітинової кислоти визначали методом Лата. Встановлено, що загальний вміст амінокислот у нативному зерні у пророщеному в водних розчинах та пророщеному в розчині із вмістом йодиду калію (КI) збільшується від 288,8 до 443,6 та до 562,6 мкг/2 сухих речовин, відповідно. Вивчено вміст фітинової кислоти та встановлено, що ї вміст у нативному зерні становить 29,3 г/кг, пророщеному у водних розчинах - 8,6 г/кг, пророщеному у розчині КI - 3,2 г/кг. 3 проведеного експерименту можливо зробити висновок, що процес пророщення зерен сої у розчинах КI впливає на збільшення вмісту амінокислот майже на 50 \%. Завдяки високій гідрофільності білка у 2 рази збільшується маса пророщених зерен. Припускаємо, що розчин із КІ є синергістом інактивацї фітинової кислоти. Проведений комплекс дослідження є науковою основою для використання зазначеної сировини в технології м'ясних виробів для осіб із хронічними колітами та йододефіцитними станами.
\end{abstract}

Ключові слова: білкові харчові продукти, зерна сої, процес пророщення, акумульований йод, йод-дефiцитні стани.

Received date: 27.01.2020

Accepted date: 24.02 .2020

Published date: 30.04 .2020
Copyright (C) 2020, Biletska Y., Semeniuk A., Perepelytsia A. This is an open access article under the CC BY license (http://creativecommons.org/licenses/by/4.0)

\section{Introduction}

Providing the population with ecologically pure protein products of plant origin is an important task of national importance in any country [1]. However, the native use of soybeans today is limited due to the presence of antinutritional substances in them, namely the content of phytic acid. It stops the fermentation of the oligosaccharides of raffinose and stachiosis, which, getting into the intestine, are absorbed with the release of gases [2]. In a healthy adult, the stomach and intestines contain about 1 liter of gas, while consuming legumes, the volume of gas removed can reach three or more liters. The accumulation of gases is affected by the quantitative content of phytic acid [3]. Phytic acid is an antinutrient that binds nutrients in the digestive tract, reducing their absorption and removing them from the body as waste. It is possible to reduce the phytic acid content in legumes during germination [4], during which the phytate content decreases by $30-50 \%$ [5]. Plant protein, which is the main component of legumes, has the ability to accumulate inorganic trace elements, transforming them into organic forms during soaking during germination [6, 7]. The aforementioned question is of particular relevance given the prevalence of iodine deficiency states [8]. A method of producing germinated soybean grain in an aqueous extract of kelp Laminaria japonica or Laminaria saccharina is well-known, which includes hydromechanical processing of grain and grinding [9]. The proposed method allows to obtain a product with iodine content, but the disadvantage of this method is the low iodine content. Also, scientists have not studied how the process of germination affects the change in the amino acid composition of grain. Therefore, the aim of this work is to study the effect of various conditions of soybean germination on the change in amino acid composition, and the content of phytic acid. This is relevant and timely, and will solve the problem of iodine deficiency diseases and chronic colitis. This study is of particular importance given the possible use of these raw materials in the technology of meat products. 
So, the object of research is selected «Diamond» early ripe soybean variety with a protein content of $43.88 \%$, 2018 harvest from the Agrotek collection nursery (Kyiv, Ukraine).

\section{Methods of research}

The characteristics of the soaking solutions are as follows: the concentration of potassium iodide in the soaking solution is $38 \mathrm{~g} / 1000 \mathrm{~cm}^{3} \mathrm{H}_{2} \mathrm{O}$, which corresponds to the iodine content in the solutions of $41 \mu \mathrm{g} / \mathrm{g}$ and satisfies $1 / 3 \%$ of the daily iodine requirement. The grain is soaked for 48 hours. Analysis of the amino acid composition of the studied samples is carried out by ion exchange chromatography on an AAA T-339m amino acid analyzer (Czech Republic) and a Shimadzu LC-20 chromatograph (Japan). Samples weighing $0.3 \mathrm{~g}$ are poured into $10 \mathrm{~cm}^{3}$ of distilled water and $10 \mathrm{~cm}^{3}$ of concentrated hydrochloric acid. Samples are placed in a dry oven with a temperature of $130{ }^{\circ} \mathrm{C}$ for 8 hours. After that, they are filtered through a filter and washed with distilled water. The resulting solution is transferred to a porcelain cup and evaporated on an electric stove to a volume of $0.5-1.0 \mathrm{ml} \mathrm{pH}$ (optimal $2.2 \pm 0.02$ units) is measured. The resulting sample is passed through a $0.45 \mu \mathrm{m}$ diameter membrane filter. They are introduced into the chromatographic ion-exchange column of the AAA T-339m analyzer. Further, the analysis is carried out automatically and lasted 115 minutes. After the analysis is completed, the obtained chromatograms are decrypted and the peak areas of each amino acid are calculated. Tryptophan during acid hydrolysis of the protein almost completely decomposes, therefore, its determination is carried out on a Shimadzu LC-20 TM liquid chromatograph. The sample is subjected to alkaline hydrolysis $(\mathrm{NaOH})$ at $100{ }^{\circ} \mathrm{C}, 16-18$ hours in the presence of $5 \%$ tin chloride). The hydrolyzate after neutralization with a mixture of citric and hydrochloric acids (for the prevention of drag) is analyzed on an amino acid analyzer. The phytic acid content is determined by the Lott method, which is based on the discoloration of phytic acid with a solution of the complex anion of iron disulfosalicylate to brown [10].

\section{Research results and discussion}

The influence of various conditions of germination on the change in the amino acid composition of soybean is investigated. The research results are shown in Table 1.

From the experiment it is possible to conclude that the process of germination affects the change in amino acid composition in the direction of its increase. The total content of essential amino acids, such as valine, isoleucine, tyrosine + phenylalanine, lysine, methionine, threonine tryptophan, arginine, histidine increases from 148 (in native grain) to 238.7 (in sprouted in aqueous solutions) and to 289.7 (germinated in solution with a content of KI) $\mu / g$ of dry matter. The total amino acid content increases from 288.8 to 443.6 and to $562.6 \mu \mathrm{g} / \mathrm{g}$ dry matter, respectively. Obviously, the process of soybean germination in KI solutions affects the increase in amino acid content by almost $50 \%$. Due to the high hydrophilicity of the protein, the mass of germinated grains increases by 2 times, which is an important factor in the manufacture of sausages.
Investigation of the influence of various conditions of soybean germination on the change in amino acid composition

\begin{tabular}{|c|l|c|c|c|}
\hline No. & \multicolumn{1}{|c|}{ Amino acids } & \multicolumn{3}{|c|}{$\begin{array}{r}\text { Thentent in grains of soybeans, } \\
\text { mcg of dry matter }\end{array}$} \\
\hline \multicolumn{2}{|l|}{ Essential amino acids: } & $\begin{array}{c}\text { Native } \\
\text { grain }\end{array}$ & $\begin{array}{c}\text { Germinated in } \\
\text { aqueous solution }\end{array}$ & $\begin{array}{c}\text { Germinated } \\
\text { in KI solution }\end{array}$ \\
\hline 1 & valine & 15.7 & 26.2 & 31.9 \\
\hline 2 & isoleucine & 13.6 & 21.6 & 26.4 \\
\hline 3 & leucine & 22.3 & 38.1 & 42.0 \\
\hline 4 & tyrosine+phenylalanine & 24.7 & 45.9 & 47.1 \\
\hline 5 & lysine & 26.3 & 37.3 & 52.8 \\
\hline 6 & methionine & 3.4 & 5.0 & 6.8 \\
\hline 7 & threonine & 9.1 & 14.7 & 18.4 \\
\hline 8 & tryptophan & 4.3 & 6.6 & 8.2 \\
\hline 9 & arginine & 21.1 & 29.5 & 41.0 \\
\hline 10 & histidine & 7.9 & 13.8 & 15.1 \\
\hline Essential amino acids content & 148.4 & 238.7 & 289.7 \\
\hline Nonessential amino acid: & & & \\
\hline 11 & cystine & 2.1 & 3.1 & 4.1 \\
\hline 12 & alanine & 12.9 & 18.0 & 22.2 \\
\hline 13 & aspartic acid+asparagine & 33.3 & 59.1 & 67.6 \\
\hline 14 & glycine & 10.8 & 13.2 & 20.0 \\
\hline 15 & glutamic acid+glutamine & 63.0 & 90.9 & 122.1 \\
\hline 16 & serine & 18.1 & 20.6 & 36.9 \\
\hline Total amino acids content & 288.6 & 443.6 & 562.6 \\
\hline
\end{tabular}

The content of phytic acid in native soybean grain was studied, which amounted to $29.3 \mathrm{~g} / \mathrm{kg}$. In the sprouted in aqueous solution $-8.6 \mathrm{~g} / \mathrm{kg}$. In the sprouted in KI solution $-3.2 \mathrm{~g} / \mathrm{kg}$. Let's assume that the process of soybean germination affects the reduction of phytic acid due to the launch of enzymatic processes that occur during shoot germination, and KI solutions are synergists of this process.

\section{Conclusions}

Having studied the effect of various conditions of soybean germination on the change in amino acid composition, it is found that the total content of essential amino acids increases from 148 (in native grain) to 238.7 (in sprouted in aqueous solutions) and to 289.7 (sprouted in a solution with KI content) $\mu \mathrm{g} / \mathrm{g}$ of dry matters. The total amino acid content increases from 288.8 to 443.6 and to $562.6 \mu \mathrm{g} / \mathrm{g}$ of dry matter, respectively. Having studied the influence of various conditions of germination on the phytic acid content, it is found that native soybean grain contains $29.3 \mathrm{~g} / \mathrm{kg}, 8.6 \mathrm{~g} / \mathrm{kg}$ germinated in aqueous solutions, and $3.2 \mathrm{~g} / \mathrm{kg}$ germinated in a KI solution.

\section{References}

1. Uiliams, K., Senders, T. (2000). Sviaz mezhdu zdorovem i potrebleniem belka, uglevodov i zhira. Voprosy pitaniia, 3, 54-57.

2. Arsenieva, L. Yu., Bondar, N. P., Usatiuk, S. I. (2017). Doslidzhennia zminy khimichnoho skladu nasinnia bobovykh pid chas proroshchuvannia ta ekstruduvannia. Khranenye y pererabotka zeran nauchno praktycheskyi portal. Available at: http:/ hipzmag.com/tehnologii/pererabotka/doslidzhennya-zminihimichnogo-skladu-nasinnya-bobovih-pid-chas-proroshhuvannya-ta-ekstruduvannya/ 
3. Bohdanov, H. O., Holovchenko, O. V., Arsenieva, L. Yu., Bondar, N. P. (2004). Perspektyvy ta bezpechnist vykorystannia nasinnia biloho liupynu dlia vyrobnytstva kharchovykh produktiv. Visnyk ahrarnoi nauky, 11, 57-61.

4. Abramova, E. P., Chernikov, M. P. (1964). Soderzhanie ingibitorov proteinaz $\mathrm{v}$ semenakh nekotorykh bobovykh. Voprosy pitaniia, 4, 13-14.

5. Obertiukh, Yu. V. (2012). Antypozhyvni rechovyny soi, yikh inaktyvatsiia ta tekhnolohii pererobky soievykh bobiv na promyslovii osnovi v umovakh hospodarstva. Kormy $i$ kormo vyrobnytstvo, 71, 62-72. Available at: http://www.irbis-nbuv.gov.ua/cgi-bin/ irbis_nbuv/cgiirbis_64.exe?C21COM=2\&I21DBN=UJRN\&P21 DBN=UJRN\&IMAGE FILE DOWNLOAD $=1 \&$ Image file name $=$ PDF/kik_2012_71_10.pdf

6. Biletska, Y., Plotnikova, R., Danko, N., Bakirov, M., Chuiko, M., Perepelytsia, A. (2019). Substantiation of the expediency to use iodine-enriched soya flour in the production of bread for special dietary consumption. Eastern-European Journal of Enterprise Technologies, 5 (11 (101)), 48-55. doi: http://doi.org/ 10.15587/1729-4061.2019.179809

7. Biletska, Y., Plotnikova, R., Skyrda, O., Bakirov, M., Iurchenko, S., Botshtein, B. (2020). Devising a technology for making flour fromchickpea enriched with selenium. Eastern-European Journal of Enterprise Technologies, 1 (11 (103)), 50-58. Available at: https://doi.org/10.15587/1729-4061.2020.193515

8. Ryzhkova, T., Bondarenko, T., Dyukareva, G., Biletskaya, Y. (2017). Development of a technology with an iodine-containing additive to produce kefir from goat milk. Eastern-European
Journal of Enterprise Technologies, 3 (11 (87)), 37-44. doi: http:// doi.org/10.15587/1729-4061.2017.10382

9. Kravchenko, M. F., Kryvoruchko, M. F., Pop, T. M. (2012). Pat No. 69515. UA. Sposib otrymannia boroshna z soi, proroshchenoho $u$ vodnomu ekstrakti laminarii laminaria japonica abo laminaria saccharina. MPK A23 L 1/325. No. 2011141882. declareted: 30.11.11.; published: 25.04.2012;. Bul. No. 8.

10. Titok, V. V., Vakula, S. I., Leontev, V. N. (2015). Analiz strukturnikh kachestvenykh osobenostei deponirovaniia fitina $\mathrm{v}$ zrelykh semenakh lna maslichnogo. Tsitoloiia $i$ genetika, 49 (1), 40-45.

Biletska Yana, PhD, Associate Professor, Department of International Ecommerce and Hotel and Restaurant Business, V. N. Karazin Kharkiv National University, Ukraine, e-mail: ya.belecka@karazin.ua, ORCID: https://orcid.org/0000-0001-8060-6579

Semeniuk Alina, Department of International Ecommerce and Hotel and Restaurant Business, V. N. Karazin Kharkiv National University, Ukraine,e-mail: alinasemenuk@icloud.com, ORCID: https://orcid.org/ 0000-0001-7412-2084

Perepelytsia Anna, PhD, Department of International Ecommerce and Hotel and Restaurant Business, V. N. Karazin Kharkiv National University, Ukraine, e-mail: irtb@karazin.ua, ORCID: http://orcid.org/ 0000-0002-2306-7975 